\title{
Radicle Emergence Test Estimates Predictions of Percentage Normal Seedlings in Standard Germination Tests of Aubergine (Solanum melongena L.) Seed Lots
}

\author{
Eren OZDEN*, Cihat OZDAMAR, Ibrahim DEMIR \\ Ankara University, Faculty of Agriculture, Department of Horticulture, 06110, Diskapi, Ankara, \\ Turkey; erozden@ankara.edu.tr (*orrespondingauthor); cihatozdamar@hotmail.com;demir@agri.ankara.edu.tr
}

\begin{abstract}
An experiment was made to test the potential for radicle emergence (RE), and predict the germination percentage of normal seedlings both at constant $\left(25^{\circ} \mathrm{C}\right)$ and fluctuating $\left(20 / 30^{\circ} \mathrm{C}, 16 \mathrm{~h} / 8 \mathrm{~h}\right)$ temperatures for 23 commercially available Thiram treated and untreated aubergine (Solanum melongena L.) seed lots. Frequent counts of RE at 96, 104, 112, 120, 128 and 136 hours in two different temperature regimes (constant and alternating) consistently predicted final normal germination after 14 days. The $R^{2}$ values at fluctuating temperatures $\left(R^{2}=0.69\right.$ and $\left.0.88, \mathrm{p}<0.001\right)$ were generally higher than those at a constant $\left(R^{2}=0.60-0.63, \mathrm{p}<0.01\right)$ temperature. Among the 23 seed lots, nine were Thiram threated. The $R^{2}$ relationship in both temperature regimes were reduced (for Thiram-threated seed lots ranging between $R^{2}=0.60-0.79$ at $25^{\circ} \mathrm{C}$ and $20 / 30{ }^{\circ} \mathrm{C}$ respectively, and for untreated lots ranging between $R^{2}=0.68-0.91$ at $25{ }^{\circ} \mathrm{C}$ and $20 / 30{ }^{\circ} \mathrm{C}$, respectively). Cumulative germination was slightly higher in the lots kept at fluctuating temperatures than in those kept at a constant temperature. The results showed that the RE test (i.e. $104 \mathrm{~h}$ count) can be used to make quick and repeatable predictions of the percentage of normal seedlings in aubergine lots. Moreover it was also significantly related to mean germination time $(\mathrm{MGT})$ values at constant $\left(R^{2}=0.769, \mathrm{p}<0.001\right)$ and alternating temperatures $\left(R^{2}=0.861, \mathrm{p}<0.001\right)$.
\end{abstract}

Keywords: alternating temperatures, constant temperature, germination predictions, seed vigour, Thiram treatment Abbreviations: MC: moisture content; MGT: mean germination time; RE: radicle emergence test

\section{Introduction}

The standard germination test of crop seeds for use by growers and for seed laboratory testing is evaluated from a count of normal seedlings in germination tests (ISTA, 2017). This can take place at various periods, depending on the species, and can be as high as 28 days in such species as parsley (ISTA, 2017). A quicker estimation method for normal seedling percentages would be valuable, in that higher normal seedling percentages are likely to emerge in the field and in transplant modules, especially under stressful conditions. The radicle emergence test, as set out in the ISTA Rules, as a vigor test for maize (Zea mays L.), oilseed rape (Brasica napus L.) and radish (ISTA, 2017; Powell and Mavi, 2016), although it has also shown potential also for other species (Lv et al., 2016).

There has been some research interest in the use of the $\mathrm{RE}$ test for the estimation of normal seedling counts during a germination, with seed lots with low levels of germination taking longer to reach the RE stage in maize, pepper and radish (Matthews and Khajeh-Hosseini, 2006; Demir et al., 2008a; Mavi et al., 2014). Recently, a test of seed lots of oilseed rape that had been in uncontrolled storage for several years, showed that the rate of RE, measured either as a mean germination time (MGT) or as a count of RE at 48 hours, was related significantly to a wide range of percentages of normal seedlings in the standard test (Khajeh-Hosseini et al., 2010). Similar results were also reported in radish by Mavi et al. (2016), who concluded that the rate of RE would be worth investigating for the prediction of normal seedlings in commercially available lots.

Differences in RE rates have been attributed to the length of the delay from the start of imbibition to RE (Matthews and Khajeh-Hosseini, 2007), and this delay has been interpreted as dependent upon the time required for metabolic repair before RE. A greater delay before RE in aged seed suggests that they require more time for the repair 
178

of previously sustained deterioration, and this is the basis of the ageing/repair hypothesis (Matthews et al., 2012). Aubergine is a summer vegetable crop that is produced mainly in the Mediterranean basin in Europe. It germinates slowly and is produced through transplants and ageing i.e. left over seeds reduce normal germination percentages. In this regard, an early and quick determination of normal seedling development potential can be valuable.

$\mathrm{RE}$ test conditions can influence test results, in that germination rate is related directly to germination temperature i.e. germination occurs more quickly at the optimum temperature. The higher the temperature, the faster the RE rate. As temperature deviates from the optimum, germination occurs more slowly. ISTA (2017) suggests a $20 / 30{ }^{\circ} \mathrm{C}$ fluctuating temperature for standard laboratory germination tests of aubergine seeds.

Thiram treatment is a routine application aimed at protecting seeds from fungi infection in commercial seed production. Seed companies use fungicides to protect seeds free from seed-born disease, however RE may be affected by Thiram treatment, since the fungicide will be absorbed with the water uptake as the seeds imbibe.

We aimed in this work to use radicle emergence test (RE) to predict (estimate) normal seedling production potential of commercially available aubergine seed lots after 14 days proposed by ISTA (2017). Furthermore, the effects of Thiram treatment of seeds, as well as two germination temperature regimes, on the rate of RE and their effects on prediction of normal seedling percentages were examined.

\section{Materials and Methods}

\section{Biologicalmaterial}

A total of 23 aubergine (Solanum melongena L.) seed lots, produced by various seed companies in Turkey, were obtained in January and March 2016, of which nine had been treated with fungicide (Thiram). The number of the Thiram treated lots were used as obtained from the companies. Details of the lots are given in Table 1. Twenty three lots belong to the four cultivars i.e. 5 lots to 'Aydin Siyahı' and 'Kemer', 7 lots to 'Pala', 6 lots to 'Topan'. Production year of the lots were changed between 2008 and 2016. The seed lots were hermetically sealed in aluminium foil packets and stored at $5^{\circ} \mathrm{C}$ before and during for the duration of the experiment.

\section{Experimental procedure}

Seed moisture content (MC) was determined using the low constant temperature oven method (ISTA, 2017) on two replicates of $1 \mathrm{~g}$ seeds (dried at $103^{\circ} \mathrm{C}$ for 17 hours) and is expressed on a fresh weight basis. For the testing, four replicates containing 50 seeds per lot and temperatures (constant and alternating) were placed in Petri dishes on two germination papers (Whatman No: 5, $90 \mathrm{~mm}$ diameter), and moistened with $4 \mathrm{ml}$ distilled water. The Petri dishes were then placed in plastic bags to prevent water loss during the test and held at $25^{\circ} \mathrm{C}$ at constant and alternating temperatures of $20^{\circ} \mathrm{C} / 30^{\circ} \mathrm{C}(16 \mathrm{~h} / 8 \mathrm{~h})$ in the dark. RE (radicle emergence, $2 \mathrm{~mm}$ ) was calculated in frequent counts of radicle emergence after 96, 104, 122, 120,128 and $136 \mathrm{~h}$. At the final count, 14 days after the commencement of the test, the seedlings were classified as either normal or abnormal according to International Seed Testing Association (ISTA, 2017). The mean germination time (MGT) was calculated for each lot using the formula cited by Ellis and Roberts (1980) given below,

$\mathrm{MGT}=\sum \mathrm{n} . \mathrm{D} / \sum \mathrm{n}$

where, $n=$ number of seeds newly germinated $(2 \mathrm{~mm}$, radicle emergence) at time $\mathrm{D}$ at $25^{\circ} \mathrm{C}$ and alternating temperatures of $20{ }^{\circ} \mathrm{C} / 30{ }^{\circ} \mathrm{C}, \mathrm{D}=$ days from the beginning of the germination test, $\Sigma \mathrm{n}=$ final germination.

\section{Statistical procedures}

A linear regression analysis using SPSS was used to relate radicle emergence test and normal seedling germination percentages at constant and alternating temperatures, and in the Thiram treated and untreated lots.

\section{Results}

The 23 seed lots produced a similar range of normal seedlings (\%) in the germination tests, varying between 75 and 96 percent at $25^{\circ} \mathrm{C}$; and 79 and 94 percent at $20 / 30^{\circ} \mathrm{C}$ (Table 1). All seed lots had the normal germination at the commercially required level of 75 percent. Seed moisture contents ranged between 7.08 and 11.12 percent. Two seed lots from each cultivar were treated with Thiram, apart from cultivar of 'Aydın Siyahi', from which three lots were treated. The relationship between the rate of RE and the final percentage of normal seedlings of the lots was examined.

A single early count of RE at between 96 and 136 hours since germination were predictive of percentage normal seedlings at $25{ }^{\circ} \mathrm{C}$ constant $\left(R^{2}>0.60, \mathrm{p}<0.01\right.$ in all relationships), as seen in Fig. 1 ; and $20 / 30^{\circ} \mathrm{C}$ alternating temperatures $\left(R^{2}>0.68, \mathrm{p}<0.001\right.$ all six relationships), as seen in Fig. 2.

Thus, in all, 60 percent of the variation in the percentage of normal seedlings at $25^{\circ} \mathrm{C}$ germination and 68 percent at a $20 / 30^{\circ} \mathrm{C}$ fluctuation was accounted for by the regression with counts of between 96-136 hours of the RE count. The highest relationship, $R^{2}$ values were seen at 104 hours. They were observed as 0.62 and 0.88 at constant and fluctuating temperatures, respectively.

The relationship between RE 104 hours and the normal seedling percentages of the Thiram treated and untreated seed lots showed that $R^{2}$ values ( 0.68 and 0.91 versus 0.60 and 0.79 ) were higher at alternating temperatures (Fig. 3). The seed lots not treated with Thiram had higher regression values than those that were untreated in both temperature regimes. The highest significance was shown at $20 / 30{ }^{\circ} \mathrm{C}$ with non-treated seeds, at $0.91 \mathrm{p}<0.001$ (Figure 3 ). RE test $104 \mathrm{~h}$ count was also highly related to MGT values. Regression values was higher at alternating temperatures $\left(R^{2}=0.86 \mathrm{p}<0.001\right)$ than that of constant one $\left(R^{2}=0.769 \mathrm{p}\right.$ $<0.001)$ (Fig. 4).

\section{Discussion}

The findings of this study reveal that an RE test can be used as a predictor of the percentage of normal seedlings produced in aubergine seed lots. The use of commercially 
Table 1. Normal (N, well developed shoot and root structure) and abnormal (A, missing main root, cotyledon, glassy hypocotyl etc.) seed germination percentages of 23 aubergine seed lots belong to four different cultivars ('Aydın Siyahi', 'Kemer', 'Pala' and 'Topan') at $25^{\circ} \mathrm{C}(24 \mathrm{~h}$, constant) or alternating temperatures of $20 / 30{ }^{\circ} \mathrm{C}(16 \mathrm{~h} / 8 \mathrm{~h})$ for over 14 days. Thiram treatment (+, -) and production year of the lots were also mentioned

\begin{tabular}{|c|c|c|c|c|c|c|c|}
\hline \multirow{3}{*}{ Cultivar } & \multirow{3}{*}{ Seed lots } & \multicolumn{4}{|c|}{ Normal (Abnormal) Seed Germination (\%) } & \multirow{3}{*}{$\begin{array}{l}\text { Thiram } \\
\text { Treated }\end{array}$} & \multirow{3}{*}{ Production Year } \\
\hline & & \multicolumn{2}{|c|}{$25^{\circ} \mathrm{C}-24 \mathrm{~h}$} & \multicolumn{2}{|c|}{$20 / 30{ }^{\circ} \mathrm{C}-16 / 8 \mathrm{~h}$} & & \\
\hline & & $\mathrm{N}(\mathrm{A})$ & MGT & $\mathrm{N}(\mathrm{A})$ & MGT & & \\
\hline \multirow{6}{*}{ 'Aydın siyahı' } & $\mathrm{Al}$ & $89(6)$ & 4.4 & $87(10)$ & 4.8 & + & 2015 \\
\hline & $\mathrm{A} 2$ & $83(4)$ & 4.9 & $86(11)$ & 5.2 & - & 2014 \\
\hline & A3 & $82(7)$ & 4.8 & $84(10)$ & 5.4 & + & 2015 \\
\hline & A4 & $95(3)$ & 4.5 & $92(7)$ & 4.2 & + & 2015 \\
\hline & A5 & $81(12)$ & 5.3 & $83(12)$ & 5.3 & - & 2014 \\
\hline & $\mathrm{K} 1$ & $75(10)$ & 5.8 & $79(17)$ & 6.0 & - & 2016 \\
\hline \multirow{3}{*}{ 'Kemer' } & $\mathrm{K} 2$ & $81(5)$ & 4.5 & $91(5)$ & 4.6 & + & 2014 \\
\hline & $\mathrm{K} 3$ & $90(4)$ & 4.2 & $92(5)$ & 4.7 & - & 2016 \\
\hline & K4 & $79(10)$ & 5.7 & $85(10)$ & 5.2 & + & 2014 \\
\hline \multirow{8}{*}{ 'Pala' } & K5 & $75(18)$ & 5.2 & $87(11)$ & 4.9 & - & 2016 \\
\hline & P1 & $76(5)$ & 4.6 & $83(3)$ & 5.5 & - & 2016 \\
\hline & P2 & $87(2)$ & 3.9 & $94(4)$ & 4.4 & - & 2008 \\
\hline & P3 & $81(12)$ & 5.6 & $93(4)$ & 4.6 & + & 2015 \\
\hline & P4 & $75(1)$ & 5.0 & $88(4)$ & 4.7 & - & 2010 \\
\hline & P5 & $86(3)$ & 4.2 & $94(5)$ & 4.3 & - & 2008 \\
\hline & P6 & $76(7)$ & 6.8 & $94(4)$ & 4.2 & + & 2015 \\
\hline & P7 & $76(4)$ & 5.1 & $87(5)$ & 5.2 & - & 2010 \\
\hline \multirow{6}{*}{ ‘Topan’ } & $\mathrm{T} 1$ & $87(4)$ & 3.8 & $94(4)$ & 4.5 & - & 2016 \\
\hline & $\mathrm{T} 2$ & $91(5)$ & 4.3 & $89(3)$ & 4.9 & - & 2013 \\
\hline & T3 & $80(3)$ & 4.5 & $88(4)$ & 4.7 & + & 2016 \\
\hline & $\mathrm{T} 4$ & $84(39$ & 3.5 & $93(6)$ & 4.0 & - & 2016 \\
\hline & $\mathrm{T} 5$ & $96(3)$ & 4.0 & $85(8)$ & 4.9 & - & 2013 \\
\hline & T6 & $91(2)$ & 3.4 & $89(5)$ & 4.6 & + & 2016 \\
\hline
\end{tabular}
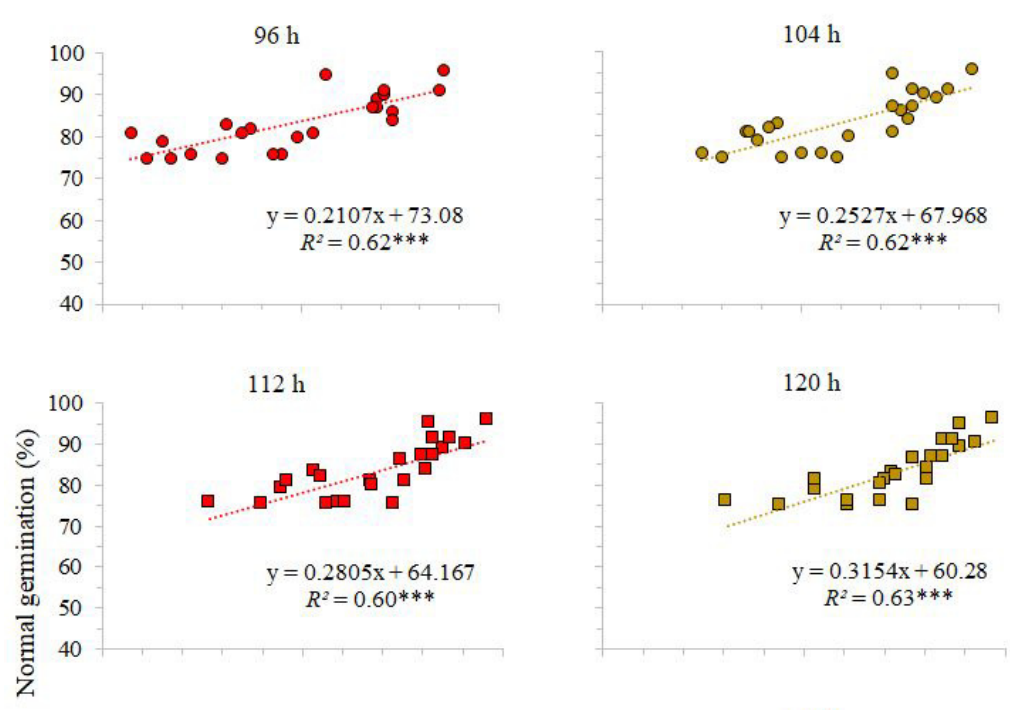

$120 \mathrm{~h}$

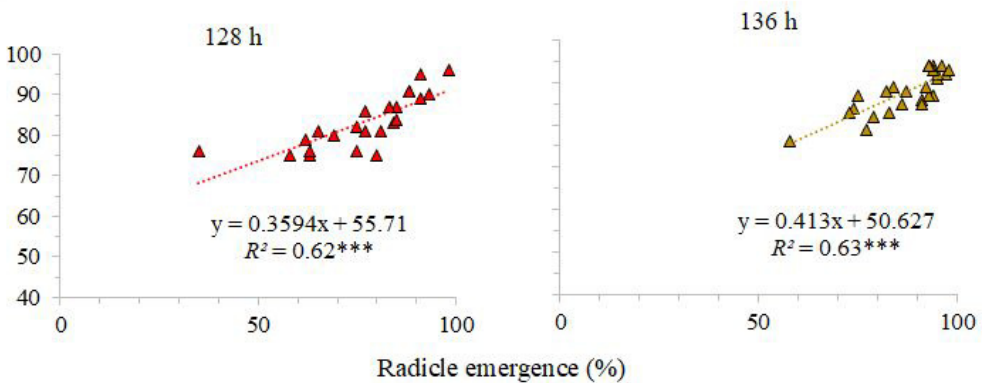

Fig. 1. The relationship between RE counts at $25^{\circ} \mathrm{C}(24 \mathrm{~h}$, constant) with different hours and normal germination percentages in 23 aubergine seed lots. Significance ${ }^{* * *}: \mathrm{p}<0.001$ 
180
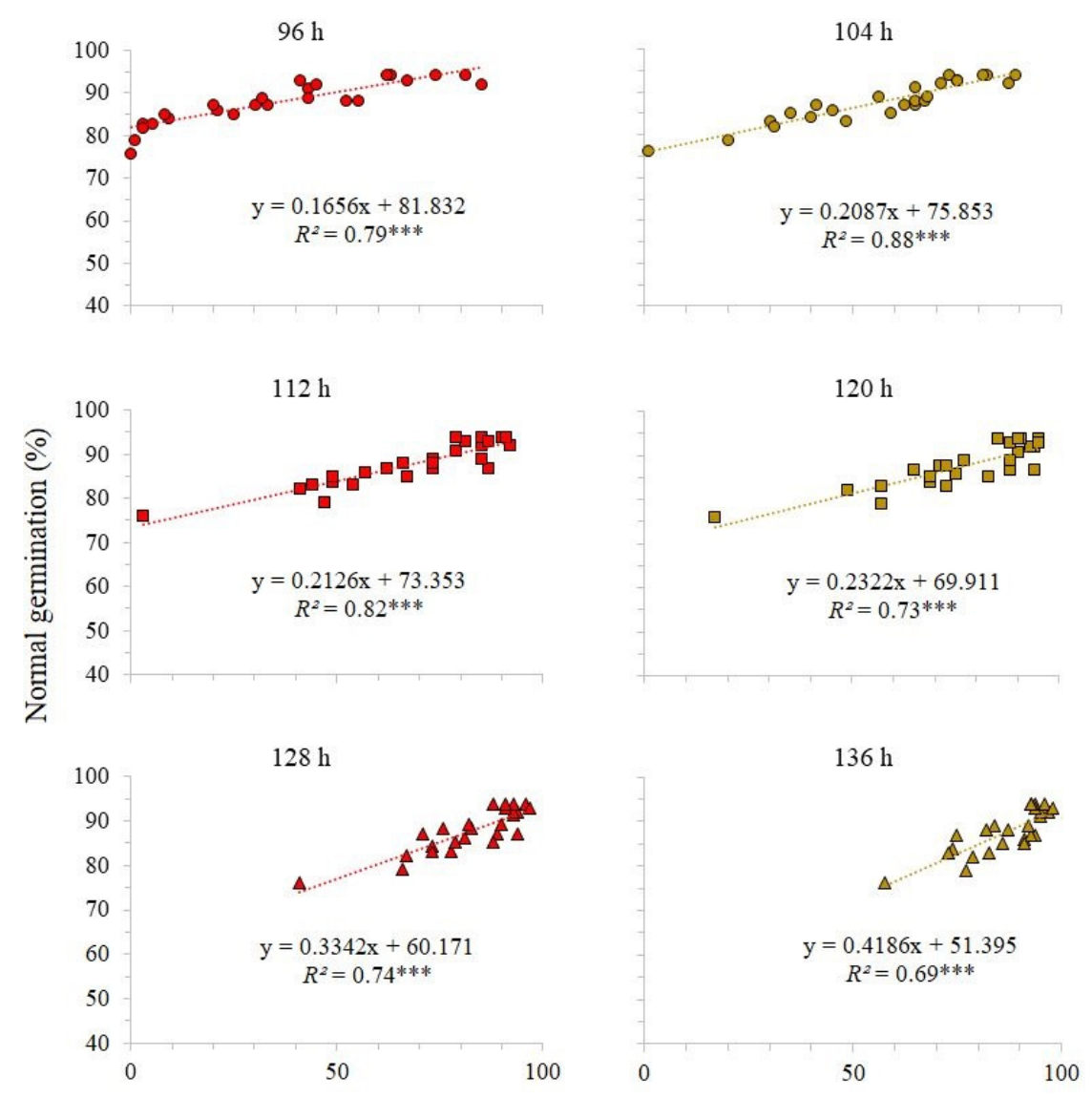

Radicle emergence (\%)

Fig. 2. The relationship between RE counts at $20 / 30{ }^{\circ} \mathrm{C}(16 \mathrm{~h} / 8 \mathrm{~h})$ alternating temperatures with different hours and normal germination percentages in 23 aubergine seed lots. Significance ${ }^{* * *}: \mathrm{p}<0.001$

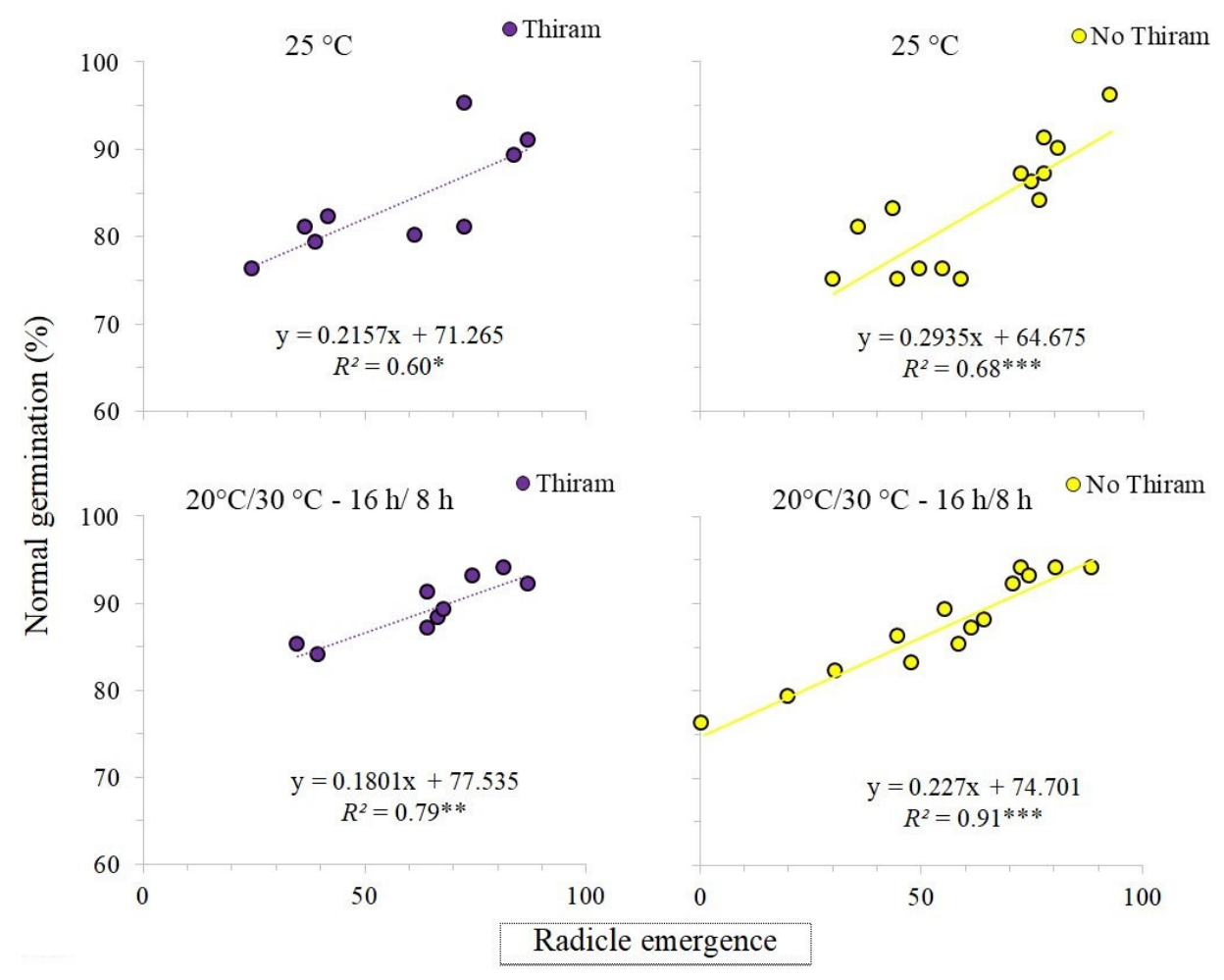

Fig. 3. Relationship between $\mathrm{RE}$ counts at $25^{\circ} \mathrm{C}$ and $20 / 30{ }^{\circ} \mathrm{C}$ alternating temperatures for $104 \mathrm{~h}$ and normal germination percentages in Thiram treated ( $\bullet, 9$ lots) and untreated (, 14 lots) aubergine seed lots. Significance ${ }^{*}: \mathrm{p}<0.05,{ }^{* *}: \mathrm{p}<0.01,{ }^{* * *}: \mathrm{p}$ $<0.001$ 


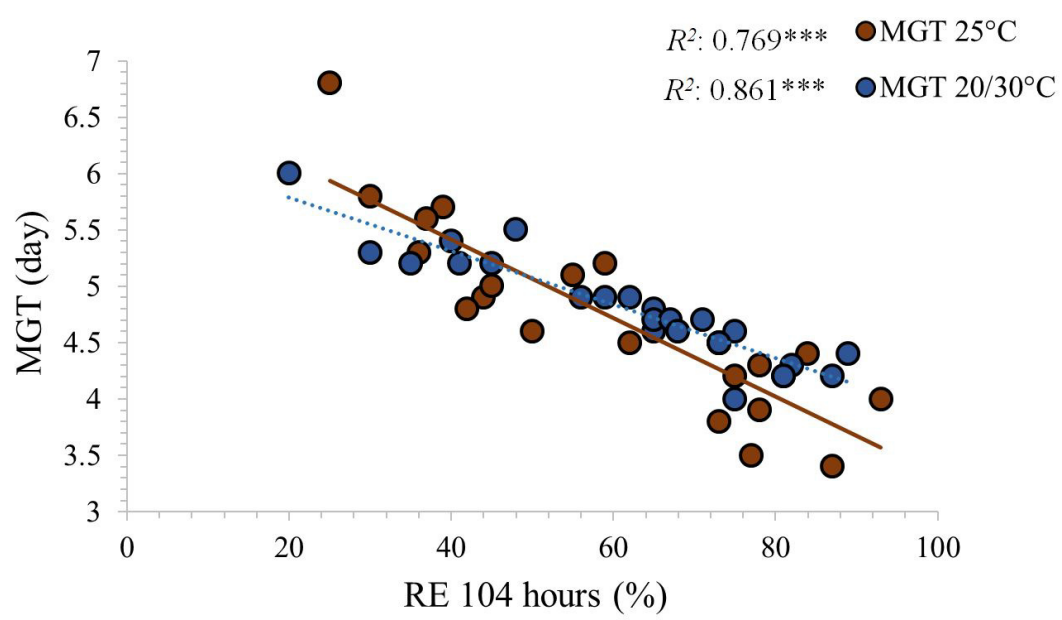

Fig. 4. The relationship between RE count at $104 \mathrm{~h}$ and mean germination time (MGT) in 23 aubergine seed lots germinated at $25^{\circ} \mathrm{C}$ and $20 / 30^{\circ} \mathrm{C}$, alternating temperatures; significance: ${ }^{* * *}: \mathrm{p}<0.001$

available seed lots with more than 75 percent normal seedlings ensured a realistic approach that involved a range of germinations that were above the minimum commercially required level available on the market.

The potential for the use of an RE test for the assessment of seed vigor has been mentioned in studies of crop seeds. Using 20 seed lots of oilseed rape with a wide range of normal seedlings, ranging from 10 to above 90 percent after several years of uncontrolled storage, KhajehHosseini et al. (2010) found that a single count of RE after 48 hours was related significantly to normal seedling counts. This may also apply to other crops in which early counts of normal seedlings are regarded as a marker of high quality, in that, from our observations and those of many seed analysts, seeds producing early normal seedlings are among the earliest to produce a radicle. The rate of radicle emergence has already been validated as a vigor test, indicating field emergence in maize, oilseed rape (ISTA, 2017) and radish (Powell and Mavi, 2016). More recent work have shown that single counts can relate to field emergence in the forage species Avena sativa L. and Elymus nutans Griseb. (Lv et al., 2016), and the same was seen in aubergine seeds in the present study from the high regression of determination between 104-hour RE and MGT (Fig. 4). An RE count at 104 hours was also highly predictive of normal germination (\%), indicating its clear potential as a test of normal germination. Future work on these and other species as forthcoming research goals may show that normal seedling counts can also be predicted through early counts of RE, or that normal germination levels of seed lots can be estimated within a short period, i.e. a few days.

The mean germination time (MGT) based on radicle emergence in the germination tests was predictive of normal germination (Mavi et al., 2016). MGT determination involves several counts of radicle emergence as the germination progresses. Frequent counts throughout the germination test may not be easy for a large number of lots, however, practical automated methods used as part of a routine have been developed (Demilly et al., 2014).

A higher proportion of abnormal seedlings and a slower $\mathrm{RE}$ are associated with seed ageing in wheat (Guy and Black, 1998) and sunflower (Bailly et al., 2002), while slower germination (high MGT) has been linked to seed ageing (measured by accelerated ageing or controlled deterioration) in several other crop species (Matthews and Powell, 2011). Artificial ageing decreases the proportion of normal seedlings and increases solute leakage in radish (Mavi et al., 2016) and cabbage (Demir et al., 2008b). Matthews and Khajeh Hosseini (2007) have pointed out that MGT is the mean lag period, from the start of imbibition to RE. It was suggested that the length of the lag period is determined by the age of the seed and the time needed for the repair of deterioration as a result of ageing (Matthews et al., 2012).

Fungicidal treatment is widely used in the seed sector to control seed performance and seed and soil-borne fungal pathogens. Many of these treatments improve emergence when disease pressure is high or when seeds are under environmental stress. Seeds that do not undergo treatment are likely to rot before emerging in the soil, and so seed lots are often fungicide treated prior to seed testing, and this may be the case for left-over seed lots as well. Our results reveal that the relationship between RE and normal germination percentages in both treated and untreated seed lots are significant, except in one case. In general $R^{2}$ in the Thiram-treated seed lots was slightly lower than in the untreated lots (Fig. 3).

In all counts, seed germination at fluctuating temperatures increased the regression values between the $\mathrm{RE}$ and normal germination percentages than under the constant temperature regime (Figs. 1 and 2). The fluctuating temperature regime was found to promote seed germination percentages and rates (Ellis and Barret, 1994). It would appear that aubergine also responds to fluctuating temperatures positively, promoting faster radicle emergence, although the relationship between RE and normal germination remains significant under both temperature regimes (Figs. 1 and 2).

Mavi et al. (2016) suggest that the radicle emergence test provides small laboratories with the opportunity to gain early information on the eventual count of normal seedlings. They claim that this may be applicable to many species and could be investigated further in routine testing. Automatic RE counting methods could facilitate early counts of RE in seed lots at a larger scale. Exact predictions 
182

of normal germination may not be possible, but laboratories may provide a quick guide as to which seed lots may or may not be suitable for sale. This may be more applicable for low quality seed lots that are left over from earlier seed production seasons, which can occur when seeds are stored in subtropical conditions i.e. in high humidity and temperatures. Successful results in RE test in various quality seed lots in our work has confirmed that.

\section{Conclusions}

This work has showed that RE test has a potential to predict normal seedling percentages of aubergine seed lots. $\mathrm{R}^{2}$ values between $\mathrm{RE}$ and normal seedling percentages were higher in alternating than those of constant temperatures and in untreated with Thiram than Thiram treated ones. The RE test $(104 \mathrm{~h})$ was also highly related to mean germination time. It can be concluded that RE can be used for a quick evaluation of seed quality.

\section{References}

Bailly C, Bogatek-Leszcznsko R, Côme D, Corbineau C (2002). Changes in antioxidant enzymes and lipoxygenase during growth of sunflower seedlings from seeds of different vigour. Seed Science Research 12:47-55.

Demilly D, Ducournau S, Wagner MH, Dürr D (2014). Digital imaging of seed germination. In: Dutta Gupta S, Ibaraki Y (Eds). Plant Image Analysis: Fundamentals and Applications. CRC Press, Boca Raton, USA pp 147-162.

Demir I, Ermis S, Mavi K, Matthews S (2008a). Mean germination time of pepper seed lots (Capsicum annuum) predicts size and uniformity of seedlings in germination tests and transplant modules. Seed Science and Technology36:21-30.

Demir I, Mavi K, Kenanoglu BB, Matthews S (2008b). Prediction of germination and vigour in naturally aged commercially available seed lots of cabbage (Brassica oleracea var. capitata) using the bulk conductivity method. Seed Science and Technology 36:509-523.

Ellis RH, Roberts EH (1980). Towards a rational basis for testing seed quality. In: Hebblethwaite PD (Ed.) Seed Production. Butterworths, London, UKpp 605-635.
Ellis RH, Barret S (1994). Alternating temperatures and rate of seed germination in lentil. Annals of Botany 74:519-524.

Guy PA, Black M (1998). Germination-related proteins in wheat revealed by differences in seed vigour. Seed Science Research 8:99-111.

ISTA (2017). International Rules for Seed Testing, International Seed Testing Association, Bassersdorf, Switzerland.

Khajeh-Hosseini M, Nasehzadeh M, Matthews S (2010). Rate of physiological germination relates to the percentage normal seedlings in standard germination tests of naturally aged seed lots of oilseed rape. Seed Science and Technology 38:602-611.

Lv YY, Wang YR, Powell AA (2016). Frequent individual counts of radicle emergence and mean just germination time predict seed vigour of Avena sativa and Elymus nutans. Seed Science and Technology 44:189-198.

Matthews S, Khajeh-Hosseini M (2006). Mean germination time as an indicator of emergence performance in soil of seed lots of maize (Zea mays). Seed Science and Technology 34:339-347.

Matthews S, Khajeh-Hosseini M (2007). Length of the lag period of germination and metabolic repair explain vigour differences in seed lots of maize (Zea mays L.). Seed Science and Technology 35:200-212.

Matthews S, Powell AA (2011). Towards automated single counts of radicle emergence to predict seed and seedling vigour. Seed Testing International 142:44-48.

Matthews S, Noli E, Demir I, Khajeh-Hosseini M, Wagner MH (2012). Evaluation of seed quality: from physiology to international standardisation. Seed Science Research 22:69-73.

Mavi K, Mavi F, Demir I, Matthews S (2014). Electrical conductivity of seed soak water predicts seedling emergence and seed storage potential in commercial seed lots of radish. Seed Science and Technology 42:76-86.

Mavi K, Powell AA, Matthews S (2016). Rate of radicle emergence and leakage of electrolytes provide quick predictions of percentage normal seedlings in standard germination tests of radish (Raphanussativus). Seed Science and Technology 44:393-409.

Powell AA, Mavi K (2016). Application of the radicle emergence test to radish (Raphanus sativus) seed. In: Method Validation Reports 2016. International Seed Testing Association, Basserdorfpp 65-72. 